\title{
INTELIGENTNI SAOBRAĆAJ I PAMETNI GRADOVI: KAKO VELIKIM PODACIMA OČUVATI EKOLOŠKU BEZBEDNOST
}

\author{
Stefan Vučićević ${ }^{1}$ \\ $\mathrm{UDK}=004.6: 351.777(1-21)$ \\ https://doi.org/10.18485/fb_ubur.2018.1.ch13 \\ ${ }^{1}$ Univerzitet u Beogradu, stvucicevic@gmail.com
}

\section{Sažetak}

Usled sve većeg stepena urbanizacije, gradovi i gradske vlasti se susreću sa problemima koji se tiču kvaliteta komunalnih usluga, a posledično i kvaliteta života u gradu. Prema podacima Ujedinjenih nacija, stepen urbanizacije nastaviće da raste sve bržim tempom. Procenjuje se da će do 2050 . godine $66 \%$ svetske populacije živeti u gradovima. Ovo predstavlja problem sa stanovišta održivosti, pa će prioritetna oblast urbanizma biti dugoročno održivo uređenje života u gradu, vodeći računa o unapređenju kvaliteta života uz pomoć tehnologije. Jedna od glavnih dilema održivosti urbanog života jeste pitanje lične mobilnosti, odnosno koje su prednosti i izazovi saobraćaja u 21. veku. Sve brža migracija stanovništva ka gradu predstavlja problem, jer postaje teško pružiti saobraćajne usluge svim žiteljima grada. Pored toga, veća pristupačnost prevoznih sredstava znači veći broj automobila na ulicama, odnosno viši stepen zagađenosti vazduha i životne sredine uopšte. Takođe, neophodno je rešiti i pitanje utroška resursâ, ali i prelaska na održive oblike energije, kao što je solarna.

Jedno od rešenja problema utroška energije jeste ideja pametnih gradova, sveopšteg koncepta koji služi da uz pomoć rešenjâ iz oblasti informaciono-komunikacionih tehnologija (IKT) i Internet of Things (IoT) poboljša kvalitet života. Ideja pametnih gradova jeste da upravljamo svim sredstvima jedne urbane sredine kako bismo unapredili iskustvo građana $i$ u realnom vremenu procenili efikasnost rešenja koje primenjujemo u gradu. Time se postiže bolja komunikacija između građana i gradskih vlasti, što dovodi do uspešnije koordinacije potreba stanovnika i njihovog ispunjenja.

Osnovne oblasti primene koncepata i rešenja pametnih gradova jesu zdravstvo, školstvo, upravljanje vodom, otpadom, komunalnim uslugama, prevoznim sredstvima i saobraćajnom infrastrukturom. Uz pomoć sistema za praćenje stanja u realnom vremenu i podataka koje prikupljaju senzori uspevamo da uočimo poteškoće, ali još važnije - ovi podaci se mogu iskoristiti za prediktivnu analitiku i preduprediti kasniji problemi. Upotrebna vrednost ovog znanja ogleda se u prilici da uz pomoć njega smanjimo troškove, unapredimo planiranje, smanjimo uticaj na životnu sredinu, što sve zajedno doprinosi višem kvalitetu života u gradu. Dakle, pametni grad ne treba shvatiti kao urbanu sredinu opremljenu tehnologijom, već grad koji uspeva da iskoristi tehnologiju radi unapređenja kvaliteta života.

U tom smislu, saobraćaj je jedna od glavnih oblasti u kojoj se razvijaju i testiraju rešenja za pametne gradove, usled uticaja koji saobraćaj vrši na gradske zajednice. Pod saobraćajem se misli na prevoz ljudi, transport robe i usluga, trgovinu, drumski, vazdušni i vodni 
saobraćaj, infrastrukturu koja podržava saobraćaj, učesnike saobraćaja, njegov uticaj na privredu - dakle, u velikoj meri saobraćaj oblikuje izgled života u gradu. Saobraćaj i urbanizacija neraskidivo su povezani, gde problemi koji se tiču održivosti urbanizacije stvaraju probleme održivosti saobraćaja u gradskim sredinama, i obratno. Stoga inicijative koje žele da sprovedu ideju pametnog grada obavezno moraju rešiti i probleme saobraćaja.

Sistem inteligentnog saobraćaja nastaje kao inicijativa koja uključuje različite napredne tehnologije koje sakupljaju velike količine podataka i omogućavaju korisnicima bolje i bezbednije odlučivanje o učešću u saobraćaju. Sistem inteligentnog saobraćaja predstavlja široki skup aplikacija koje uključuju rešenja kao što su sistem za upravljanje saobraćajnim signalima, navigacija automobila, upravljanje policijskim radarom, pametni sistemi parkiranja, informacije o vremenskim prilikama.

U ovom radu predstaviću tri koncepta u okviru sistema inteligentnog saobraćaja: a) sistem pametnog parkiranja, b) sistem za procenu i predikciju saobraćaja i c) paradigmu mobility as a service, kao i primere njihove upotrebe radi očuvanja ekološke bezbednosti u pametnim gradovima.

Sistem pametnog parkiranja odnosi se na upotrebu podataka prikupljenih iz senzora postavljenih na parkiralištima koji pružaju uvid u situaciju na određenim parkiralištima. Koristeći prikupljene podatke, sistem vrši nekoliko funkcija - smanjuje vreme i gorivo koje vozači utroše tražeći parking-mesto u urbanim sredinama, redukuje gužvu na ulicama, jer smanjuje broj vozača koji traže parking-mesto, uvodi fleksibilni sistem naplate parkinga stimulišući nižim cenama parkiranje na neatraktivnim lokacijama i destimulišući parkiranje u samom centru. Sistem takođe prikuplja informacije o broju slobodnih parking-mesta na lokaciji i potom saopštava te podatke vozačima, što smanjuje emisiju $\mathrm{CO}_{2}$, kao što je urađeno u okrugu Vestminster u Londonu.

Sistem za procenu i predikciju saobraćaja obuhvata širok skup procesa koji prate, analiziraju i kontrolišu tok saobraćaja i optimizuju njegovu efikasnost. Kako bi sistem inteligentnog saobraćaja mogao funkcionisati, neophodno je da uzima veliki broj podataka, poželjno u realnom vremenu i iz različitih izvora, što bi omogućilo donošenje relevantnih odluka, a iziskuje upotrebu prediktivne analitike.

Paradigma mobility as a service predstavlja iskorak u odnosu na prethodna dva pristupa saobraćaju u pametnim gradovima, jer predstavlja suštinsku promenu modela - od sopstvenih automobila prelazi se na model prevoza koji se pruža kao usluga. Složenost ove paradigme iziskuje postojanje pametnih telefona, podataka, saradnje prevoznika i mobilnih operatera, ali i fizičku, infrastrukturnu podršku koja će omogućiti razmenu podataka. Ovom razmenom stiče se uvid u obrasce kretanja, što doprinosi optimizaciji infrastrukturne mreže, pa samim tim i efikasnijem saobraćaju i manjim troškovima, a posredno i većoj ekološkoj bezbednosti, kao što je pokazano u slučaju Helsinkija i aplikacije Whim (http://maas.global/whim).

Ključne reči: pametni grad, javni transport, big data, ekološka bezbednost 


\section{Uvod}

Prema podacima Ujedinjenih nacija, ${ }^{1} 2016$. godine $54,5 \%$ svetske populacije živelo je u gradskim naseljima. Procenjuje se da će stepen urbanizacije nastaviti da raste sve bržim tempom i da će do 2030 . godine $27 \%$ svetskog stanovništva živeti u gradovima sa najmanje milion stanovnika. I pored toga što tehnologija omogućava rad sa fizički udaljenih lokacija u realnom vremenu, pa zahvaljujući tome ne moramo živeti u gradu u kojem radimo, i uprkos sve rasprostranjenijem pristupu internetu, očekuje se da se kretanje stanovništa ka gradu nastavi u budućnosti, i da će se do 2050. godine preko $66 \%$ svetske populacije nastaniti u gradovima.

Međutim, pojam grada je šarolik i u svojoj definiciji ne obuhvata kvalitet života, već se pre svega fokusira na broj ljudi koji živi u naselju i na površinu gradskog naselja. U dokumentu Ujedinjenih nacija s početka ovog rada navodi se da ne postoji standardna definicija gradskog naselja. Za potrebe ovog rada, uzećemo da je grad mesto u kojem veliki broj ljudi živi i radi.

Države gde se očekuje da migracija ka gradu bude najosetnija jesu zemlje u razvoju, i to pre svega na afričkom kontinentu, što predstavlja dvojak problem: sa jedne strane, treba obezbediti sredstva za razvoj i podršku urbanizma, a, sa druge strane, dolazećem stanovništvu treba obezbediti poslove, infrastrukturu, saobraćaj, stambeni smeštaj, školstvo, lečenje, energetske resurse. Ovaj trend predstavlja problem sa stanovišta održivosti, jer će gradske vlasti imati sve teži zadatak da pruže bazične usluge svojim sugrađanima. Prioritetna oblast urbanizma biće dugoročno održivo uređenje života u gradu, vodeći računa o unapređenju kvaliteta života uz pomoć tehnologije.

Jedno od glavnih pitanja održivosti urbanog života jeste pitanje lične mobilnosti, odnosno pitanje prednosti i izazova saobraćaja u 21. veku, u trenutku kada većinski deo populacije živi u gradovima. Sve brže kretanje stanovništva ka gradu predstavlja problem, jer postaje teško pružiti saobraćajne i druge infrastrukturne usluge svim stanovnicima grada. Pored toga, veća pristupačnost prevoznih sredstava znači veći broj automobila na ulicama, a u krajnjoj meri i viši stepen zagađenosti vazduha i životne sredine uopšte. U ovom kontekstu, neophodno je rešiti i pitanje prelaska na održive oblike energije, kao što je solarna.

Jasno je da mnogi faktori utiču na kvalitet saobraćaja u gradu. Ovaj rad baviće se načinima na koje tehnologija može da pomogne u izazovima sa kojima se susreću službe gradskog saobraćaja i gradske vlasti, na primeru velikih podataka i pametnih gradova, a u cilju očuvanja ekološke bezbednosti.

1 Publikacija UN World's cities in 2016. 


\section{Veliki podaci}

Kako bi se predstavila uloga tehnologije u rešavanju problema saobraćaja u gradu, a time i većoj ekološkoj bezbednosti, neophodno je objasniti koncept velikih podataka (big data). ${ }^{1}$ Termin veliki podaci odnosi se na disciplinu koja analizira, obrađuje i skladišti velike količine podataka. Suština ove specijalnosti je da pruži korisne informacije obradom i analizom velikih nepovezanih skupova podataka. Praktično gledano, ova stručna oblast treba da poboljša prethodno stanje sistema. Pristup koji se koristi u ovoj disciplini može se primeniti u velikom broju drugih domena, kao što su preduzetništvo, menadžment, politika, sprečavanje prevarnih radnji, analize trendova, predviđanje i preskriptivne mere.

Potreba za ovom disciplinom nastala je uporedo sa sve boljim načinima obrade i prikupljanja podataka, kao i sve većim memorijskim kapacitetima. S obzirom na sve veću količinu podataka koje stvaraju korisnici interneta, sve su veće tehničke mogućnosti za skladištenje tih podataka. Međutim, skladištenje podataka nije cilj sámo po sebi. Cilj je uočiti informacije, odnosno pronaći značenje prikupljenih podataka, a potom te informacije iskoristiti za efikasnije donošenje odluka. Disciplinu velikih podataka treba posmatrati kao disciplinu koja će stalno pratiti razvoj ostalih srodnih oblasti, pre svega onih koje se odnose na unapređenje hardvera i softvera.

Primera radi, prikupljaju se podaci o broju zauzetih parking-mesta u Beogradu u toku jedne radne sedmice. Cilj nije prikupiti te podatke na jednome mestu, već uočiti najzauzetije delove grada u toku dana, a onda raditi na rešenju tog problema. Uz ovu analizu mogli bi se upotrebiti podaci o vremenskim uslovima i sagledati da li se situacija menja u zavisnosti od vremena.

Prema Thomas et al. (2015), nekoliko je karakteristika podataka kojima se ova disciplina bavi:

a) Podaci moraju biti velikog obima.

b) Podaci se generišu velikom brzinom.

c) Podaci potiču iz različitih izvora.

d) Podaci imaju odgovarajući kvalitet.

e) Podaci imaju saznajnu vrednost.

Postoje četiri grane ove discipline: deskriptivna analitika, dijagnostička analitika, prediktivna analitika i preskriptivna analitika.

Deskriptivna analitika se koristi da opiše uočene trendove. U primeru sa saobraćajem u Beogradu deskriptivna analitika bi pružila opise stanja u saobraćaju. Na primer, bilo bi poznato koliko prosečno automobila pređe Brankov most, ili koristi parking na Zelenom vencu, koliko je prosečno kašnjenje autobusa ili tramvaja, koliko je taksi-vozila na ulicama.

Dijagnostička analitika bi odgonetnula zapažene trendove. Bilo bi poznato zašto se dogodio zastoj u saobraćaju određenog dana; ili u kojim delovima grada može da dođe do najvećeg zakrčenja saobraćajnica.

1 Ne postoji jedan ustaljeni prevod ovog termina, pa se često zadržava izvorni naziv na engleskom. U ovom radu koristiće se termin veliki podaci. 
Prediktivna analitika ukazala bi gde će i kada biti najveća gužva ili najmanji broj slobodnih parking-mesta. Shodno tome, moglo bi se raditi na poboljšanju stanja u saobraćaju.

$\mathrm{Na}$ kraju, preskriptivna analitika bi pružila uvid u skup pravila za unapređenje saobraćaja. Počevši od opisa, preko dijagnostike i onda zajedno sa predikcijama, moglo bi se reagovati pre nego što se dogodi problem u saobraćaju i tako izbeći nepotrebno zadržavanje. Ovo bi posebno bilo od koristi službama hitne pomoći, vatrogasnoj službi ili policiji, jer bi posao mogli da obavljaju efikasnije, imajući kod sebe podatke o trenutnom stanju u saobraćaju.

Dakle, veliki podaci mogu poslužiti svim učesnicima saobraćaja da dobiju korisne informacije koje bi unapredile saobraćaj i pozitivno uticale na ekološku bezbednost. Posebno je važno što je uz pomoć velikih podataka moguće efikasnije praćenje i upravljanje gradom - od čisto istorijskih podataka prešlo bi se u potpunosti na podatke koji nastaju u svakom trenutku. To bi omogućilo bolji rad različitih segmenata gradskih službi.

\section{Pametni gradovi}

Da bi urbanizacija bila održiva, gradovi moraju odgovoriti na nove izazove koji proističu iz sve većeg priliva stanovništva ka gradu. U tom smislu, već nekoliko godina unazad širom sveta se radi na izgradnji pametnih gradova. Termin pametni grad predstavlja sveopšti koncept koji služi da uz pomoć informaciono-komunikacionih tehnologija (IKT) i rešenja zasnovanih na Internet-u of Things (IoT) ${ }^{1}$ poboljša kvalitet života.

Ideja pametnih gradova je upravljati svim sredstvima jedne urbane sredine radi unapređenja iskustva građana i pravovremene procene učinkovitosti rešenja koja se primenjuju u gradu. Ovime se postiže bolja komunikacija između građana i gradskih vlasti, što dovodi do bolje koordinacije potreba stanovnika i njihovih ispunjenja. Osnovne oblasti primene koncepata i rešenja pametnih gradova jesu zdravstvo, školstvo, upravljanje vodom, otpadom, komunalnim uslugama, prevoznim sredstvima i saobraćajnom infrastrukturom.

U literaturi se susreće nekoliko različitih naziva za pojam pametnih grado$\mathrm{va}^{2}$ i uglavnom se odnose na iste činioce koji grad čine pametnim. U svom radu o integrativnom okviru pametnih gradova Chourabi et al. (2012) ističu osam faktora neophodnih za izgradnju pametnih gradova: menadžment i organizacija, tehnologija, upravljanje, politike, ljudi i zajednice, privreda, izgrađena infrastruktura i životna sredina. Ovaj rad će se pre svega osvrnuti na tehnologiju, infrastrukturu i okruženje.

1 Internet stvarî.

2 Inteligentan grad, umrežen grad, fleksigrad, sveprisutni grad, sajbervil, digitalni grad. 
Većina autora koja se bavi temom pametnih gradova ističe tehnologiju kao jedan od vodećih činilaca pametnih gradova. Rešenja koja se koriste za „opamećivanje“ gradova uglavnom počivaju na tehnološkim dostignućima. Pre svega, skup softvera, hardvera i mreže čini osnovu koja omogućava prikupljanje podataka i usklađenost svih učesnika u saobraćaju - od vozača, dispečera, njihovih mobilnih telefona, aplikacija koje koriste, pa do samih senzora postavljenih na parkiralištu ili saobraćajnoj infrastrukturi. Softver se primenjuje na postojeću infrastrukturu tako da ona može komunicirati sa krajnjim korisnicima, kao i centralnim mestom gde se svi podaci skupljaju. Ovo je efikasno rešenje, jer omogućava komunikaciju u realnom vremenu, kao i analizu i rano reagovanje.

Međutim, Chourabi et al. (2012) navode nekoliko mogućih problema u vezi sa tehnologijom. Prvo, neophodno je organizovati programe obuke iz oblasti IT kako bi se svi stanovnici grada upoznali sa rešenjima koja su im na raspolaganju. Zatim, važno je preduprediti nejednakosti u pristupu tehnologiji. Cilj tehnologije u pametnim gradovima moraju biti rasprostranjenost i dostupnost boljeg kvaliteta života svima, pa stoga treba krenuti od primene rešenja koja su besplatna ili pristupačna, široko rasprostranjena i koja pozitivno utiču na širu sliku samog grada.

Pored tehnologije, pametni grad u velikoj meri zavisi od IKT infrastrukture. Neophodno je raditi na izgradnji hardvera koji će omogućiti razmenu podataka. Infrastruktura, međutim, podrazumeva i institucionalnu infrastrukturu, te je u tom smislu neophodno unaprediti proces saradnje između vladinih sektora i obezbediti e-upravu koja će podržati pametna rešenja.

Konačno, u središtu pametnih gradova nalazi se održivost izvorâ energije i očuvanje životne sredine. Pametna tehnologija treba da se iskoristi kako bi se očuvale vodene i zelene površine u gradu, unapredila energetska održivost u sredinama sa sve većim brojem stanovnika, jer je cilj da stanovništvo koje se doseljava u grad ima prijatno okruženje za život. Dakle, pametni grad ne treba shvatiti kao urbanu sredinu opremljenu tehnologijom, već grad koji uspeva da iskoristi tehnologiju da unapredi kvalitet života.

\section{Pametni saobraćaj}

Saobraćaj je jedna od glavnih oblasti u kojoj se razvijaju i testiraju rešenja za pametne gradove, zbog uticaja koji saobraćaj ima na gradske zajednice. Pod saobraćajem se misli na prevoz ljudi, transport robe i usluga, trgovinu, drumski, vazdušni i vodni saobraćaj, infrastrukturu koja podržava saobraćaj, učesnike saobraćaja, njegov učinak na privredu - dakle, u velikoj meri saobraćaj oblikuje izgled života u gradu. Saobraćaj i urbanizacija neraskidivo su povezani, gde problemi koji se tiču održivosti urbanizacije stvaraju probleme održivosti saobraćaja u gradskim sredinama, i obratno. Stoga inicijative koje žele da sprovedu ideju pametnog grada obavezno moraju rešiti i probleme saobraćaja.

U ovom radu biće pojednostavljena i definicija saobraćaja, tako da se odnosi na sklop infrastrukture i učesnika u saobraćaju. Dakle, pri konstruisanju 
pametnog saobraćaja treba raditi na pametnoj infrastrukturi i pametnim učesnicima saobraćaja.

Infrastrukturu čine saobraćajnice, saobraćajni znakovi, signalizacija, parking-mesta. Pošto je infrastrukturu neophodno fizički izgraditi, ona utiče na planiranje i izgradnju grada. U tom smislu, gradske vlasti moraju voditi računa da optimizuju izgradnju kako bi postigle cilj a da tom prilikom očuvaju resurse i prirodne površine u gradu. Uz pomoć velikih podataka to postaje lakše, jer će količina podataka koju prikupi infrastruktura ukazati na kritična mesta koja je neophodno rešiti, bez nepotrebnog uticaja na ostale delove grada.

Primera radi, senzori postavljeni na parking-mesta, čiji je cilj da prikupljaju i u realnom vremenu šalju podatke, ukazivaće svim učesnicima saobraćaja kada je određeno parking-mesto zauzeto ili slobodno. Ovde je posebno važno to što učesnik saobraćaja ne mora da vozi sve do parkinga kako bi tek pošto stigne shvatio da je mesto popunjeno. Već prilikom uključenja u saobraćaj algoritam koji obrađuje podatke pokazao bi preko mobilne aplikacije vozaču kuda da se uputi, čime bi se smanjila gužva u već zakrčenim delovima grada, kao i emisija štetnih gasova.

S druge strane, pametni grad nema veliku praktičnu vrednost ako ne postoje građani koji će umeti da iskoriste njegove prednosti. U tom smislu, važno je podići svest o vrednosti pametnih gradova - u ovom slučaju, pametnog saobraćaja. Građani treba da znaju kako mogu koristiti mobilne aplikacije i da razumeju da je osnovna upotrebna vrednost tih aplikacija brže se dopremiti od mesta A do mesta B. Takođe, treba ohrabrivati ljude da koriste ova pametna rešenja dok se kreću kroz grad, što bi se moglo postići objašnjavanjem konkretnih prednosti.

Na primer, cene karata za ljude koji u javnom prevozu očitavaju karte mogle bi biti niže. Time bi dispečeri javnog saobraćaja imali informacije o potrebnom broju vozila na određenoj opštini. Podaci o očitavanju karte bili bi prikupljeni na centralnome mestu, a onda bi se ti podaci mogli dostavljati i dispečerima, ali i samim građanima - gde bi se, osim informacija o broju stanica, znalo kolika je gužva u autobusu ili tramvaju koji pristiže na stanicu.

Pametni saobraćaj se može posmatrati kao okvir koji čine infrastruktura i učesnici. Ovaj okvir prati situaciju u saobraćaju u realnom vremenu i omogućava analizu podataka koje prikupljaju senzori. Time se mogu uočiti poteškoće, ali, što je još važnije - ovi podaci se mogu iskoristiti za prediktivnu analitiku i preduprediti kasniji problemi.

Upotrebna vrednost ovog znanja ogleda se u smanjenju troškova, boljem planiranu, manjem uticaju na životnu sredinu, što sve zajedno doprinosi višem kvalitetu života u gradu.

Sistem inteligentnog saobraćaja nastaje kao inicijativa koja uključuje različite napredne tehnologije. Te tehnologije sakupljaju velike količine podataka i omogućavaju korisnicima pouzdanije i kvalitetnije odlučivanje o učešću u saobraćaju. Sistem inteligentnog saobraćaja predstavlja skup aplikacija kao što su sistem za upravljanje saobraćajnim signalima, navigacija automobila, upravljanje policijskim radarom, inteligentni sistemi parkiranja, informacije o vremenskim prilikama. 
U ovom radu predstavljena su tri koncepta u okviru inteligentnog saobraćaja: a) sistem pametnog parkiranja, b) sistem za procenu i predikciju saobraćaja, kao i c) paradigma mobility as a service, uz primere njihove upotrebe radi očuvanja ekološke bezbednosti u pametnim gradovima.

Sistem pametnog parkiranja odnosi se na upotrebu podataka prikupljenih iz senzora koji se nalaze na parkiralištima. Ti podaci pružaju uvid u situaciju na određenim parkinzima. Koristeći prikupljene podatke, sistem vrši nekoliko funkcija: smanjuje vreme i gorivo koje vozači utroše tražeći parking-mesto, smanjuje gužvu na ulicama, jer smanjuje broj vozača koji traže mesto, uvodi fleksibilni sistem naplate parkinga - stimulišući nižim cenama parkiranje na neatraktivnim lokacijama, a obeshrabrujući parkiranje u samom centru. Sistem takođe prikuplja informacije o broju slobodnih parking-mesta na lokaciji i potom šalje te podatke vozačima, što smanjuje emisiju $\mathrm{CO}_{2}$, kao što je urađeno u kvartu Vestminster u Londonu.

Sistem za procenu i predikciju saobraćaja obuhvata širok skup procesa koji prate, analiziraju i kontrolišu tok saobraćaja i poboljšavaju trenutnu situaciju. Kako bi sistem inteligentnog saobraćaja mogao funkcionisati, neophodno je da prikuplja veliku količinu podataka, poželjno u realnom vremenu i iz različitih izvora, što bi omogućilo donošenje relevantnih odluka, a iziskuje upotrebu prediktivne analitike.

Paradigma mobility as a service predstavlja napredak u odnosu na prethodna dva pristupa, jer predstavlja suštinsku promenu modela - od sopstvenih automobila prelazi se na model prevoza koji se pruža kao usluga. Složenost ove paradigme iziskuje postojanje pametnih telefona, podataka, saradnje prevoznika i mobilnih operatera, ali i fizičku, infrastrukturnu podršku koja će omogućiti razmenu podataka. Ovom razmenom se stiče uvid u obrasce kretanja, što doprinosi optimizaciji infrastrukturne mreže, pa samim time i efikasnijem saobraćaju i manjim troškovima, i posredno većoj ekološkoj bezbednosti, kao što je pokazano u slučaju Helsinkija i aplikacije Whim (Global Maas, 2017).

\subsection{Sistem pametnog parkiranja}

Među glavnim problemima urbanizacije nalazi se i transport u gradskoj sredini. Uz sve veći priliv stanovnika, izazov je prilagoditi infrastrukturu tako da omogući funkcionalan život u gradu. Zato se javljaju rešenja koja koriste big data kako bi na pametan način omogućila kvalitetan saobraćaj. Suštinski, ova rešenja prikupljaju podatke putem senzora postavljenih duž celokupne infrastrukture. U realnom vremenu se dobijaju informacije koje se mogu koristiti za efikasnije upravljanje saobraćajem.

Sistem pametnog parkiranja sastoji se od fizičke infrastrukture garaža i javnih parkinga na kojima se postavljaju senzori koji prikupljaju podatke o broju zauzetih odnosno slobodnih mesta. Ovi podaci se agregiraju i putem mobilnih aplikacija dostavljaju kao korisne informacije učesnicima saobraćaja. Uz pomoć geo-mapiranja, sistem se prilagođava trenutnoj lokaciji vozača i dostavlja mu informacije o slobodnim parking-mestima. 
Pametni parking posebno dobija na značaju u delovima grada gde cirkuliše veliki broj automobila, a cilj mu je da poboljša stanje u saobraćaju, i to kroz: a) smanjenje vremena koje vozači provode tražeći parking-mesto, b) smanjenje emisije štetnih gasova iz automobila, c) obeshrabrivanje upotrebe automobila u užem centru grada i preraspodela ka manje privlačnim mestima za parking, d) personalizovanu naplatu parkiranja.

U delovima grada gde ne postoji dovoljan broj parking-mesta a smešteni su centri koji okupljaju veliki broj ljudi, pa time i automobila, iskrsava problem zakrčenja ulica. Ukoliko ne postoje uslovi da se omoguće dodatna parking-mesta, vozači koji dolaze u ovaj deo grada često provode po desetine minuta tražeći mesto. Na nivou pojedinačnog vozača ovo možda i ne deluje problematično; međutim, u velikim gradovima problem je daleko složeniji - posebno kada se uzme u obzir da se ova situacija najčešće ponavlja svakodnevno.

Osim vremena koji vozači utroše tražeći parking, povećan broj automobila znači zagušenje saobraćajnica, što često ometa javni prevoz, kao što je slučaj u Beogradu, gde ne postoji sistem metroa. Ovo može dovesti do velikih zastoja u kretanju od jedne tačke u gradu do druge, kako pojedinaca, tako i javnih službi zaduženih za bezbednost i red u gradu.

Osim zakrčenja ulica, svaki suvišni minut rada motora povećava emisiju štetnih gasova. Smanjenjem rada motora svakog pojedinačnog vozača umanjuje se i trag koji ostavlja na životnu sredinu. Time se zbirno postiže veći korak ka oslobođenju gradova od štetnih gasova.

Sistem pametnog parkiranja testira se i primenjuje u gradovima širom sveta. U Londonu, u kvartu Vestminster, jednom od najgušće naseljenih delova grada, u oktobru 2014. godine počela je primena rešenja SmartPark kompanije Smart Parking. ${ }^{1}$

Ovo rešenje predstavlja sistem od preko 3.400 tehnološki naprednih RFID senzora postavljenih ispod površine parking-mesta. Ovi senzori prikupljaju informacije o dolasku i odlasku vozila na određeno mesto, a potom te podatke prenose do softvera za upravljanje parkingom, koji ih objedninjava i analizira (SmartParking, 2014).

Informacije se zatim šalju ka aplikaciji ParkRight, koju na svojim pametnim telefonima može da instalira svaki učesnik u saobraćaju i da time pronađe najbliže slobodno mesto i dobije uputstva preko sistema za navigaciju saobraćaja kako da dođe do njega (SmartParking, 2014).

Ovim rešenjem smanjeno je vreme koji vozači provode kružeći ulicama u potrazi za parking-mestom, povećan je nivo parkiranja na mestima koja su malo udaljenija od samog centra ali su sada novčano pristupačnija. Takođe, smanjeno je vreme koje su ranije neki od vozača zloupotrebljavali ostavljajući svoja vozila na parking-mestima duže nego što je propisano. Plan je da se inicijativa proširi na ostale kvartove i da bude praćena dodatnim paketima usluga koji bi poboljšali celokupno korisničko iskustvo u saobraćaju (SmartParking, 2014).

1 https://www.smartparking.com/keep-up-to-date/case-studies/city-of-westminster-london 


\subsection{Sistem za procenu i predikciju saobraćaja}

Sistem za procenu i predikciju saobraćaja širok je koncept koji podrazumeva mrežu hardvera, softvera i ljudi zajedno usmerenih na opisivanje i predviđanje trendova u gradskom saobraćaju. Ovaj sistem koristi deskriptivnu, dijagnostičku i prediktivnu analizu kako bi uz pomoć istorijskih podataka i trenutnog stanja doneo korisne zaključke o budućnosti. Može se odnositi na uređenje gradskog prevoza, taksi-prevoza, praćenje vremenskih prilika koje utiču na saobraćaj, zatim praćenje civilnog saobraćaja, vatrogasnih službi ili službi hitne pomoći.

Baš kao u slučaju velikih podataka u preduzećima, gde ogromne količine obrađenih podataka služe menadžmentu da donese bolje odluke (Chourabi et al., 2012), sistem za procenu i predikciju saobraćaja treba da omogući učesnicima da donesu bolje odluke. Time se poboljšava protok saobraćaja na više nivoa - sistem u realnom vremenu obaveštava dispečere gradskih autobusa, vozače autobusa, vozače automobila ili korisnike gradskog prevoza o najboljim trasama za kretanje.

Pošto ova složena saobraćajna mreža u svakom trenutku stvara veliku količinu podataka, sistem za predikciju saobraćaja trebalo bi da koristi te podatke kako bi predvideo i blagovremeno pružio informacije o obrascima ponašanja u saobraćaju svim učesnicima.

Ovakvi sistemi bili su u upotrebi još pre desetak godina. Grad Singapur i kompanija „Aj-bi-em“ (IBM) sproveli su u toku 2007. godine pilot-projekat ${ }^{1}$ u kojem su merili preciznost svog sistema za predikciju drumskog saobraćaja. Sistem je koristio istorijske i trenutne podatke o saobraćaju u centralnom poslovnom delu grada, a potom predviđao kretanje i obrasce saobraćaja. Predviđanja su vršena za periode od 10, 15, 30, 45 i 60 minuta unapred, i to sa ukupnom preciznošću od preko $85 \%$. U časovima kada je bilo najviše vozila na putu, dakle kada je količina podataka bila najveća, ova preciznost iznosila je i 90\% (IBM, 2007). Ovo je značajan stepen pouzdanosti, jer omogućava dispečerima i saobraćajnim učesnicima korisne uvide o predstojećim obrascima u saobraćaju, pa se mogu doneti bolje odluke koje će prevashodno uticati na smanjenje zastoja - problem koji je bitan u megalopolisima.

\subsection{Paradigma mobility as a service}

Mobility as a service je koncept koji označava prelazak sa ličnih prevoznih sredstava na model koji prevoz posmatra kao javnu uslugu. Suštinski, prema ovome modelu, ljudi ne koriste sopstvene automobile, već poručuju uslugu prevoza u skladu sa potrebama putem sveobuhvatne mreže saobraćaja. Iako idejno ova paradigma nije novina, jer je javni prevoz sâm po sebi mobility as a service, koncept je dobio na popularnosti, zbog nekoliko trendova u saobraćaju.

Tehnološka rešenja omogućavaju sve bolji spoj različitih prevoznih sredstava u jedinstvenu mrežu gde putnici plaćaju jednu uslugu, na mesečnom ili dnevnom nivou, a onda kombinuju prevozna sredstva u zavisnosti od odredišta.

1 http://www-03.ibm.com/press/us/en/pressrelease/21971.wss 
Pojava onlajn naručivanja vožnje (e-hailing) ili zajedničkog deljenja automobila od mesta A do mesta B (carpooling, car sharing) promenila je koncept posedovanja sopstvenih automobila i, usled rastuće popularnosti ovakvih servisa, među kojima je najpopularniji Uber, ${ }^{1}$ usmerila veliki broj softverskih kompanija ka pravljenju aplikacija koje mogu da podrže komunikaciju između svih učesnika u procesu.

Izazov kod ove paradigme čini upravljanje velikim količinama podataka. U manjim sredinama broj podataka biće srazmeran broju korisnika. Međutim, problem može nastati u velikim urbanim sredinama, gde se porudžbina vožnje vrši preko jedne aplikacije koja obrađuje prikupljene podatke, prosleđuje ih drugim učesnicima u prevozu, kontroliše tok plaćanja i isplatu angažovanim vozačima. Velikom broju podataka doprinosi i činjenica da je učešće u ovom procesu otvoreno za svakoga ko poseduje automobil, pa red veličina više nije ograničeni skup taksi-udruženja, već svako ko poseduje automobil i želi da pruži uslugu.

Podaci prikupljeni u procesu mogu se iskoristiti za praćenje broja učesnika u saobraćaju, za uvid u ekološki i infrastrukturno najopterećenije delove grada i upravljanje saobraćajnom mrežom. Cilj ovog pristupa je smanjenje broja automobila na ulicama, što se prevodi u manji stepen zagađenja u gradu, i ulaganje sredstava u zelene površine umesto u izgradnju parking-mesta (Global Maas, 2017).

Primena ovog rešenja može se ilustrovati na primeru glavnog grada Finske. Šira teritorija Helsinkija ima oko 1,1 milion stanovnika. Nakon šestogodišnjeg rada na aplikaciji koja bi povezala sve učesnike saobraćaja - dakle, taksi, autobuse, železnicu na celoj teritoriji Finske - kompanija Global Maas ${ }^{2}$ lansirala je aplikaciju Whim, ${ }^{3}$ čiji je cilj da urbanu gradsku sredinu učini zelenijom i bezbednijom, istovremeno pružajući jednostavno kretanje stanovnika (Global Maas, 2017).

Mesečnom pretplatom korisnici mogu da koriste usluge prevoza kroz sva prevozna sredstva uključena u program, u zavisnosti od potrebe. To znači da jedna kartica omogućava korišćenje nekog od 2.500 taksija u centru grada, servise za iznajmljivanje automobila, sve usluge objedinjenog javnog gradskog prevoza i usluge iznajmljivanja bicikala. Pri tome, plaćanje se vrši jednom mesečno i zatim možete da se neograničeno vozite kroz Helsinki, ali i dalje po zemlji (Global Maas, 2017).

Podaci korisnika mogli bi se, uz prethodnu dozvolu, iskoristiti za formiranje znanja o putnim navikama i time uočili nedostaci i predupredili problemi u saobraćaju, ali bi se moralo voditi računa o privatnosti podataka.

1 https://www.uber.com/

2 http://maas.global/

3 https://whimapp.com/fi-en/ 


\section{Zaključak}

Moć velikih podataka u kontekstu pametnog saobraćaja od velikog je značaja za sprečavanje problemâ i uvođenje trendova koji će poboljšati saobraćaj i korisničko iskustvo u pametnom gradu. Suština velikih podataka u ovom smislu jeste izgraditi dovoljno pouzdan sistem, zasnovan na prethodnim i trenutnim podacima, koji pruža informacije o sadašnjem i predstojećem stanju na saobraćajnicama. Da bi ovo bilo moguće, potrebni su fini mehanizmi obrade podataka koji bi odstranili šum, ali i stručnjaci koji će umeti da donesu zaključke na osnovu dobijenih informacija.

Veliki podaci treba da budu u službi celokupne zajednice, a naročito u kontekstu pametnih gradova, čiji je osnovni zadatak dobrobit svih stanovnika grada. U ovom smislu, veliki podaci mogu biti od značajne pomoći, jer će ukazati na oblasti koje se mogu unaprediti, ali i doneti korist u materijalnom smislu. Sredstva koja su ušteđena mogla bi se iskoristiti za dalje unapređenje života u gradu. Pored toga, time će biti unapređena i ekološka bezbednost, pošto će bolji kvalitet saobraćaja, kao i tehnološka rešenja koja ciljaju manji utrošak energije, pomoći da se dostignu ciljevi predviđeni ekološkim standardima.

\section{Literatura}

1. Batty, M., Axhausen, K.W., Giannotti, F. et al.: 'Smart cities of the future', The European Physical Journal Special Topics, 214, 481-518, 2012.

2. Batty, M.: 'Smart cities, big data', Environment and Planning B: Planning and Design, 39, 191-193, 2012.

3. Chourabi, H., Gil-Garcia J. R., Pardo T.A., Scholl H.J., Walker S. \& Nahon K.: 'Understanding Smart Cities: An Integrative Framework', 45th Hawaii International Conference on System Sciences, 2289-2297, 2012.

4. IBM and Singapore's Land Transport Authority Pilot Innovative Traffic Prediction Tool (2007). Preuzeto 29. aprila 2017. sa sajta: http://www-03.ibm.com/press/us/en/ pressrelease/21971.wss

5. Smart City Council (2014). Smart City Readiness Guide the planning manual for building tomorrow's cities today. Smart City Council publication. Preuzeto 29. aprila 2017. godine sa: http://www.swenergy.org/Data/Sites/1/media/documents/programs/government/SmartCitiesCouncil-ReadinessGuide-11.18.13a.pdf

6. Smart Parking LTD. https://www.smartparking.com/keep-up-to-date/case-studies/ city-of-westminster-london

7. Stojkov, B. \& Resanović, M. (2016). Pametan grad u Srbiji - mogućnost sistematske implementacije. Beograd, Akademija inženjerskih nauka Srbije, Cicero.

8. Thomas, E., et al.: Big Data Fundamentals, Service Tech Press, 2016.

9. Whim (aplikacija) i kompanija Maas. http://maas.global/

10. World's Cities in 2016 (2016). United Nations publication. Preuzeto 30. aprila 2017. sa: http://www.un.org/en/development/desa/population/publications/pdf/urbanization/the_worlds_cities_in_2016_data_booklet.pdf 


\title{
INTELLIGENT TRANSPORT AND SMART CITIES: USING BIG DATA TO ENSURE ECOLOGICAL SAFETY
}

\begin{abstract}
Summary
Given the increasing degree of urbanisation, cities and city authorities face problems related to the quality of communal services, and consequently of the quality of city life. According to the United Nations data, the degree of urbanisation is poised to step up its pace. It is estimated that by $2050,66 \%$ of the world population will live in cities. This poses a problem from the perspective of sustainability, so the priority area of urbanism will be sustainable regulation of city life, taking into consideration the improvement of the quality of life using technology. One of the key issues of sustainability of urban life is the question of personal mobility, i.e. advantages and challenges of the $21^{\text {st }}$ century transport. The increasingly speedier migration of the population towards cities poses a problem as it becomes difficult to provide transport services to all city inhabitants. Also, the greater accessibility of vehicles translates into a greater number of cars on city streets, and into higher air pollution and environmental pollution at large. It is also necessary to address the issue of resource consumption and move to sustainable energy sources, such as solar energy.

One of the solutions of the issue of energy consumption is the idea of smart cities, a broad concept that deploys information-communication technology (ICT) and Internet of Things (IoT) solutions to improve the quality of life. The idea of smart cities is to use all assets of an urban space to improve citizen experience and get real-time assessment of efficiency of solutions implemented in the city. This provides for better communication between citizens and city authorities, and in turn helps improve coordination of citizens' needs and their fulfilment. The main areas where smart city concepts and solutions are implemented include healthcare, education, water and waste management, communal services, means of transport and transport infrastructure. Using the real-time monitoring system and data collected by sensors, we manage to detect difficulties, but even more importantly - these data can be used for predictive analytics and then for the prevention of subsequent problems. The value of this knowledge is seen in the opportunity to deploy it to reduce costs, improve planning, curb effects on the environment, which should altogether contribute to higher quality of life in cities. A smart city should not therefore be regarded as an urban space equipped with technology, but rather as a city that manages to use technology to improve the quality of life. In this sense, transport is one of the key areas where smart city solutions are tested and implemented, given its impact on urban communities. Transport includes transport of people, transport of goods and services, trade, road, air and water transport, infrastructure behind transport, transport participants, the impact on the economy, so it largely shapes the life in cities. Transport and urbanisation are interconnected; the issues regarding urbanisation sustainability cause the issues of transport sustainability in urban areas, and vice versa. Therefore, initiatives aiming to implement the idea of a smart city need to solve the issues regarding transport.

The intelligent transportation system has been shaped as an initiative that includes various advanced technologies collecting great amount of data and enabling users to make better
\end{abstract}


and safer decisions when taking part in transport. The intelligent transportation system is a broad set of applications that include such solutions as transport signal management, car navigation, speed cameras management, intelligent parking systems, and weather conditions information.

This paper will present three concepts within the intelligent transportation system: a) smart parking system, b) traffic estimation and prediction system and c) mobility as a service paradigm, as well as how they are implemented to preserve ecological safety in smart cities.

The smart parking system refers to the use of data collected from sensors mounted on parking lots that provide insight into the occupancy ratio of parking lots. Using the collected data, the system performs several functions - it helps drivers reduce time and fuel consumed as drivers look for a parking lot in urban areas, reduces the congestion on streets by lowering the number of drivers searching for a lot, and introduces a flexible parking fee collection system - using lower fees to encourage parking in unattractive locations and discouraging parking downtown. The system also collects data on the number of available parking lots on a location and then communicates the data to drivers, helping reduce $\mathrm{CO}_{2}$ emission, as has been done in the county of Westminster in London.

Traffic estimation and prediction system encompasses a large set of processes that monitor, analyse and control traffic flow, while optimising transport efficiency. For an intelligent transport system to function, it is necessary that it amasses data, desirably in real time and from a variety of sources, which enables making relevant decisions, and requires the use of predictive analytics.

The mobility as a service paradigm is a step forward compared to the previous two approaches to managing transport in smart cities in that it is an essential change of the model itself - it proposes moving from personal cars to a model under which transport is provided as a service. The complexity of the paradigm requires using smart phones, data, cooperation between transport providers and mobile operators, but also the physical infrastructural support that will facilitate data exchange. This exchange provides insight into movement patterns, helping optimise the infrastructure network, and therefore making transport more efficient, while reducing costs and increasing ecological safety, as was shown in Helsinki via the Whim app (http://maas.global/whim/).

Keywords: smart city, public transport, big data, ecological safety 